\title{
Using Online Simulation to Replace Clinical Practice during COVID-19
}

\author{
Yasin M Yasin ${ }^{1 *}$, Daphne Kennedy ${ }^{1}$ \\ ${ }^{1}$ Faculty of Nursing, University of Calgary, Qatar
}

Submission: June 01, 2021; Published: June 15, 2021

*Corresponding author: Yasin M Yasin, PhD, University of Calgary in Qatar, Al-Rayyan Campus, P.O. Box 2313, Doha - Qatar

\begin{abstract}
In this article, we describe the use of computer-based simulations and other technology to replace clinical hours for undergraduate nursing students during the COVID-19 pandemic. We describe the technology used and how we prepared for implementation. Most importantly, we describe how we facilitated a full clinical day online using the technology and the feedback from students about the experience. To our knowledge, this is the first example of how to facilitate a fully online clinical day using these technologies. As such, this information will guide educators as they design online instruction to overcome the restrictions related to the pandemic while continuing to ensure quality education and achievement of course outcomes.
\end{abstract}

\section{Using Online Simulation to Replace Clinical Practice During COVID-19}

Simulation-based education has been used extensively in undergraduate nursing education to replace or deepen the understanding of complex nursing concepts [1]. Historically, a variety of different levels of fidelity (realism) have been used to achieve learning needs, with all levels of fidelity (low, moderate, and high) having a strong positive impact on learning experiences [2]. With the restrictions applied to clinical practice because of the COVID-19 pandemic, students from nursing programs were prohibited from attending in-person simulation labs and clinical settings. New instructional delivery was implemented to provide an opportunity for students to replace clinical skills using innovative simulation experiences that accommodate COVID-19 restrictions. Two types of software from Elsevier (https://evolve.elsevier. com) were incorporated to provide optimal learning experiences. The first, Simulation Learning System for RN® (SLS), which is designed to support the delivery of high-fidelity simulations, was used to provide the framework for unfolding simulations that the instructor delivered using images of a simulation set up, a concept map creator, and an electronic health record. The second software, SimPractice, is a screen-based simulation software where students interact with a virtual client and make decisions about and provide nursing care. Zoom meeting software was used as a means to create telepresence and facilitate fully simulated clinical days. Simulation days were designed intentionally to provide the opportunity to apply the knowledge, skills, and behaviours required to achieve course outcomes.
Instructors and students were required to have a strong internet connection and laptops that met the required specifications. Students and faculty received training sessions about using the new software, before implementation. Furthermore, individualized support was provided as needed by two senior instructors with experience running this software. There was no need for Zoom software training as the students and instructors have previously used it. One example of the online clinical simulation day is for second-year students, where the concepts of "self-concept" and "interprofessional communication" were incorporated. Students were instructed to wear their uniforms and approach the day as they would a shift in the actual clinical setting. The day began with students watching a YouTube video about self-concept followed by a group discussion to reflect critically on the video. The students then drew a mandala that reflected a stressful event in their life and how they coped with that stress. After this activity, the instructor facilitated a group discussion of how positive and negative self-concepts can affect stress management. In order to incorporate related psychomotor skills, students completed a computerized simulation of taking vital signs using SimPractice. The instructor debriefed the students to help them make a connection between vital signs and stress. Interprofessional communication was addressed through a roleplay activity involving two students in each Zoom breakout room. Following this, the students practiced providing a handoff report in an SLS simulation. At the end of the day, students submitted a reflection on their performance, which included specific examples 


\section{JOJ Nursing \& Health Care}

of how they met evaluation criteria and how they would improve their professionalism, preparation, knowledge, and participation. The instructor then provided individual formative feedback to students.

Students enjoyed the learning experience and were appreciative of the efforts to provide practical strategies to meet learning outcomes. Carefully developed online clinical days that incorporate simulation technology may be used to replace some clinical experiences. However, several psychomotor skills that need physical contact with patients should be performed in a clinical setting. Online simulation can support clinical education but does not entirely replace it.

\section{Author's Contribution}

$1^{\text {st }}$ author carried the data collection and wrote the initial draft with input from the other author. $2^{\text {nd }}$ author reviewed the paper and verified the analytical methods. Both authors discussed the results and contributed to the final manuscript.

\section{Declaration of Interest}

The authors declare no conflict of interest.

\section{References}

1. Aebersold M (2018) Simulation-based learning: No longer a novelty in undergraduate education. The Online Journal of Issues in Nursing 23(2): 1-13.

2. Kim J Park, J Shin S (2016) Effectiveness of simulation-based nursing education depending on fidelity: A meta-analysis. BMC Medical Education 16 (1): 152.

\section{Your next submission with Juniper Publishers will reach you the below assets}

- Quality Editorial service

- Swift Peer Review

- Reprints availability

- E-prints Service

- Manuscript Podcast for convenient understanding

- Global attainment for your research

- Manuscript accessibility in different formats

( Pdf, E-pub, Full Text, Audio)

- Unceasing customer service

Track the below URL for one-step submission https://juniperpublishers.com/online-submission.php 